\title{
Influence of nutrition on feline calcium oxalate urolithiasis with emphasis on endogenous oxalate synthesis
}

\author{
J. C. Dijcker ${ }^{1}$, E. A. Plantinga ${ }^{1 *}$, J. van Baal $^{2}$ and W. H. Hendriks ${ }^{1,2}$ \\ ${ }^{1}$ Faculty of Veterinary Medicine, Utrecht University, Yalelaan 7, 3584 CL, Utrecht, The Netherlands \\ ${ }^{2}$ Animal Nutrition Group, Wageningen University, PO Box 338, 6700 AH, Wageningen, The Netherlands
}

\begin{abstract}
The prevalence of calcium oxalate $(\mathrm{CaOx})$ uroliths detected in cats with lower urinary tract disease has shown a sharp increase over the last decades with a concomitant reciprocal decrease in the occurrence of struvite (magnesium ammonium phosphate) uroliths. $\mathrm{CaOx}$ stone-preventative diets are available nowadays, but seem to be marginally effective, as CaOx urolith recurrence occurs in patients fed these diets. In order to improve the preventative measures against $\mathrm{CaOx}$ urolithiasis, it is important to understand its aetiopathogenesis. The main research focus in $\mathrm{CaOx}$ formation in cats has been on the role of $\mathrm{Ca}$, whereas little research effort has been directed towards the role and origin of urinary oxalates. As in man, the exogenous origin of urinary oxalates in cats is thought to be of minor importance, although the precise contribution of dietary oxalates remains unclear. The generally accepted dietary risk factors for CaOx urolithiasis in cats are discussed and a model for the biosynthetic pathways of oxalate in feline liver is provided. Alanine:glyoxylate aminotransferase 1 (AGT1) in endogenous oxalate metabolism is a liver-specific enzyme targeted in the mitochondria in cats, and allows for efficient conversion of glyoxylate to glycine when fed a carnivorous diet. The low peroxisomal activity of AGT1 in cat liver is compatible with the view that felids utilised a low-carbohydrate diet throughout evolution. Future research should focus on understanding de novo biosynthesis of oxalate in cats and their adaptation(s) in oxalate metabolism, and on dietary oxalate intake and absorption by cats.
\end{abstract}

Key words: Urinary calcium oxalate: Urolithiasis: Oxalate biosynthesis: Cats: Diet

\section{Introduction}

Urolithiasis is the condition in which calculi are formed in the urinary tract from initially dissolved minerals and/or organic compounds. In domestic cats, the primary stones are composed of calcium oxalate (CaOx) monohydrate or dihydrate and struvite (magnesium ammonium phosphate hexahydrate). Less common stones are purines (i.e. ammonium urate, sodium (calcium) urate, potassium urate, uric acid dihydrate and xanthine), calcium phosphate, matrix, cystine and silica uroliths ${ }^{(1)}$.

Urolithiasis in domestic cats is, after feline idiopathic cystitis (FIC), the second most common cause of lower urinary tract disease (LUTD) ${ }^{(2,3)}$. Studies with the aim to determine the incidence rates for urolithiasis have not been conducted in cats. Estimates on incidence rates reported in the literature are largely based on morbidity rates seen in veterinary practices, with estimates varying between $0 \cdot 2$ and $0 \cdot 7 \%^{(4,5)}$.
Over the past 30 years, a progressive increase in the prevalence of $\mathrm{CaOx}$ uroliths in cats diagnosed with LUTD has been reported in the USA ${ }^{(1)}$, with a similar trend being observed in Western Europe ${ }^{(6)}$. During the early 1980 s, CaOx was detected in only $2 \%$ of all feline uroliths submitted to the Minnesota Urolith Center, whereas struvite was detected in $78 \%$ of the uroliths submitted (Fig. 1) $)^{(1)}$. However, in the mid-1990s, together with a rapid increase in the total number of uroliths submitted for analysis, a notable shift in the submitted types of uroliths has been observed $^{(7)}$. In the mid-1980s, the submitted CaOx uroliths noticeably increased ${ }^{(8)}$, reaching $55 \%$ in 2002 in the USA ${ }^{(1)}$ and $61 \%$ in 2003 in Western Europe ${ }^{(6)}$. Since 2003 a slight decline in the percentage of $\mathrm{CaOx}$ uroliths has been observed, reaching $41 \%$ in 2007. This decline comes along with a reciprocal increase in the frequency of struvite uroliths, up to $49 \%$ in $2007^{(1)}$. The amount of less common uroliths (i.e. purines, calcium phosphate, etc) submitted for analysis has remained fairly constant at about $10 \%{ }^{(1)}$.

Abbreviations: AGT1, alanine:glyoxylate aminotransferase 1; BW, body weight; CaOx, calcium oxalate; FIC, feline idiopathic cystitis; GAG, glycosaminoglycan; GR/HPR, glyoxylate reductase/hydroxypyruvate reductase; LUTD, lower urinary tract disease; ME, metabolisable energy; MTS, mitochondrial targeting sequence; PH, primary hyperoxaluria; RSS, relative supersaturation.

*Corresponding author: Dr Esther A. Plantinga, fax +31 30253 7970, email E.A.Plantinga@uu.nl 
Fig. 1. Feline urolith distribution in the USA from 1981 until $2007^{(1)}$ : magnesium ammonium phosphate hexahydrate ( $\square$ ); calcium oxalate ( $\square$ ); calcium phosphate

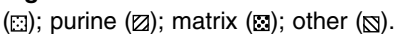

The same general trend in urolith composition can be observed in dogs but is less extreme compared with cats ${ }^{(1,6)}$.

It is generally thought that the concomitant increase in the occurrence of $\mathrm{CaOx}$ uroliths with the reciprocal decrease in struvite until 2003 reflects the widespread use of struvite urolith-preventive diets since the mid$1980 s^{(9,10)}$. These acidifying diets, often with reduced quantities of $\mathrm{Mg}$, are believed to promote calciuria and reduce urinary $\mathrm{Mg}$ concentrations, both being risk factors for $\mathrm{CaOx}$ urolith formation ${ }^{(10,11)}$. The progressive decrease in occurrence of $\mathrm{CaOx}$ uroliths from 2003 until 2007 may be associated with the improvement of adult maintenance and therapeutic diets to minimise risks for CaOx crystalluria.

Despite the use of urolith-preventive diets over the past decades, the prevalence of $\mathrm{CaOx}$ uroliths in cats remains substantial. In order to further decrease the incidence of $\mathrm{CaOx}$ urolithiasis in cats, understanding of the aetiopathogenesis of $\mathrm{CaOx}$ urolithiasis is essential. The purpose of the present review is to discuss dietary risk factors for $\mathrm{CaOx}$ urolith formation in cats, with an emphasis on the origin of urinary oxalates. Endogenous biosynthesis of oxalate in the mammalian liver is reviewed and recommendations for research in order to reduce feline $\mathrm{CaOx}$ urolithiasis by dietary intervention are provided.

\section{Risk factors}

Several risk factors have been identified for $\mathrm{CaOx}$ urolith formation in cats. The risk of developing $\mathrm{CaOx}$ uroliths appears to increase with age, with cats aged 7-10 years showing the highest predisposition ${ }^{(12)}$. Other predisposing factors seem to be sex and reproductive status, with male cats more commonly affected $(59 \%)^{(12)}$, and $95 \%$ of cats with $\mathrm{CaOx}$ urolithiasis being neutered. However, the imbalance of reproductive status in the population of cats (for example, $78 \%$ of cats examined at primary veterinary practices in the USA were neutered $)^{(4)}$ might be a confounding factor. In Burmese, Himalayan and Persian cats, a predisposition to develop $\mathrm{CaOx}$ uroliths has been observed, indicating that genetic background also contributes to CaOx urolithiasis ${ }^{(10,12,13)}$. Nevertheless, considering the short time span in which the types of feline uroliths have changed over the past three decades (Fig. 1), it is highly unlikely that animal-related factors have made a significant contribution to this observed trend, as opposed to nutritional and husbandry factors. Changes in nutrition are thought to be one of the main reasons for the epidemiologic shift in urolith type in cats ${ }^{(1)}$.

Urinary concentrations of $\mathrm{Ca}$ and oxalate play a key role in $\mathrm{CaOx}$ urolith formation. Factors indirectly influencing the formation of $\mathrm{CaOx}$ crystals are urinary volume, $\mathrm{pH}$, citrate and glycosaminoglycans (GAG) concentration. The relationship between various dietary components and the risk factors for $\mathrm{CaOx}$ urolith formation are outlined in Fig. 2. Dietary components able to influence urine volume, urinary oxalate excretion, urinary Ca excretion, urine $\mathrm{pH}$ (acidosis) and urinary citrate and GAG levels (see Fig. 2) will be discussed in more detail.

\section{Urine volume}

Theoretically, a high fluid intake could inhibit CaOx urolith formation since it dilutes the urine, thereby lowering the urinary concentrations of $\mathrm{Ca}$ and oxalate and, in turn, the crystallisation of $\mathrm{CaOx}$ in the urinary tract. Enhancing urine volume may also increase the frequency of urination, which would reduce crystalloid and crystal transit time along the urinary tract, thereby reducing the potential for crystal growth $^{(14)}$. Therefore, measures to increase water intake to promote high urine volume can be considered 


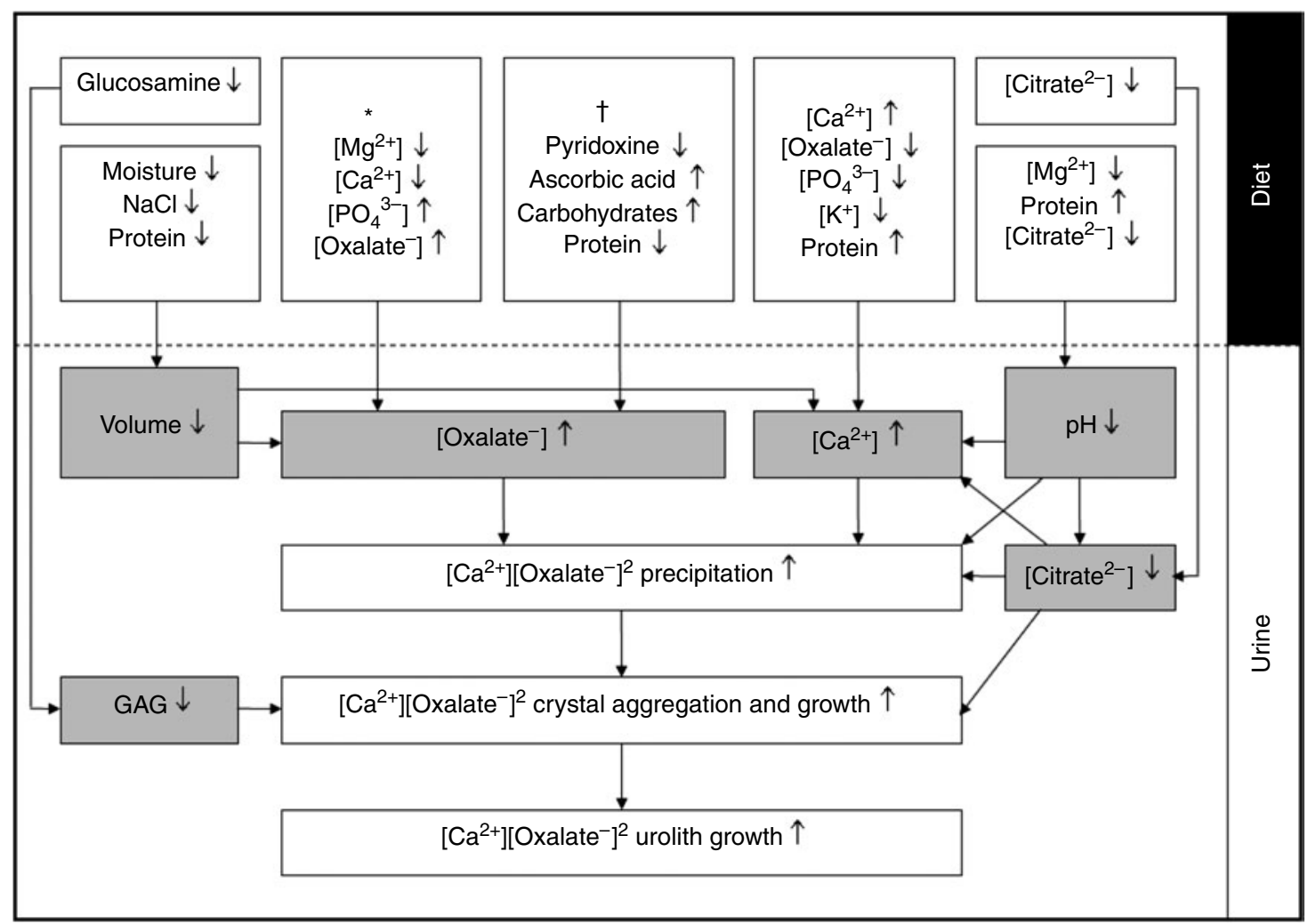

Fig. 2. Schematic model of dietary risk factors likely to increase calcium oxalate urolith formation in cats. GAG, glycosaminoglycan. * This box contains dietary factors affecting the availability of exogenous oxalate for absorption in the gastrointestinal tract. †This box contains dietary factors affecting endogenous oxalate synthesis.

as one of the best approaches to prevent urolith recurrence. A higher water intake can be achieved by feeding diets with high moisture and/or Na content.

Dietary factors affecting urine volume. Data in the literature indicate that feeding high-moisture diets to adult cats leads to a slightly higher total water intake leading to an increased urine volume ${ }^{(15,16)}$. When high (82\%)-moisture diets are fed, urine output is increased by $57.4 \%$ compared with low (10\%)-moisture diets ${ }^{(15)}$. In a retrospective case-control study with 173 cats with $\mathrm{CaOx}$ uroliths, it was found that cats fed (canned) diets containing the highest moisture contents ( $77 \cdot 4$ to $81 \cdot 2 \%)$ were only about one-third as likely to develop CaOx uroliths compared with cats fed (dry kibble) diets low in moisture $(7 \cdot 0 \text { to } 7 \cdot 9 \%)^{(9)}$. The purpose of the latter study was to identify dietary factors associated with the increase in occurrence of $\mathrm{CaOx}$ uroliths. The dietary factors studied were moisture content, protein, carbohydrate, fat and fibre content, but also $\mathrm{Ca}, \mathrm{P}, \mathrm{Mg}, \mathrm{Na}, \mathrm{K}$ and chloride content and urine-acidifying potential. Of these factors, the moisture content of the diet seemed to have the strongest association with $\mathrm{CaOx}$ urolith formation in cats ${ }^{(9)}$. The favourable effect of a high water intake on LUTD in general was also reported by Markwell et al. ${ }^{(14)}$, who stated that recurrence rates of signs in cats classified as having idiopathic LUTD, or FIC, may be more than halved when affected animals are maintained on high-, rather than low-, moisture content diets. Gunn-Moore \& Shenoy ${ }^{(17)}$ observed a significantly lower urine specific gravity in cats with FIC when they were fed more canned cat food as well.

The increased water intake when feeding moist diets might not only be due to its higher moisture content, but also because its higher mineral (ash) and protein content (evoking a higher renal solute load) may stimulate drinking ${ }^{(18,19)}$. This is in line with the finding that a high intake of animal protein is accompanied by increased water consumption and urine volume in cats ${ }^{(20)}$. Taking into account the overall beneficial effect of high-moisture diets by increasing urine volume, and therefore diluting all substances dissolved in the urine, feeding a highmoisture diet may be considered as one of the most effective measures to prevent $\mathrm{CaOx}$ formation.

Another way to increased urine volume is to stimulate drinking by increasing dietary $\mathrm{Na}$ intake ${ }^{(21,22)}$. This effect of a higher $\mathrm{Na}$ intake might explain the results of the previously mentioned retrospective case-control study with 173 cats, in which diets high in $\mathrm{Na}(0.34$ to $0.89 \mathrm{~g} / \mathrm{MJ}$ metabolisable energy (ME)) were correlated with a decreased risk of $\mathrm{CaOx}$ urolith formation ${ }^{(9)}$. In humans, an increased salt intake has been associated with elevated urinary $\mathrm{Ca}$ excretion ${ }^{(23-25)}$. Salt-induced calciuria is believed to result from $\mathrm{Na}-\mathrm{Ca}$ interactions in the kidney, in both the proximal and distal tubule. Reabsorption of 
Ca parallels the reabsorption of $\mathrm{Na}$ in the proximal tubule and loop of Henle. Na may influence renal reabsorption of $\mathrm{Ca}$ in the distal tubule by both a direct effect and indirectly through its effects on parathyroid hormone levels ${ }^{(26)}$. In a study with healthy cats, the total daily amount of $\mathrm{Ca}$ excreted in urine was reported to be increased ${ }^{(27)}$. Similar results were found in dogs ${ }^{(28,29)}$. However, in two studies with healthy adult cats, dietary $\mathrm{Na}$ levels of up to $0.96 \mathrm{~g} /$ MJ ME did not increase urine Ca concentrations, but did increase the volume of water drunk, resulting in a larger urine volume and a concomitant decrease in urine specific gravity and $\mathrm{CaOx}$ relative supersaturation (RSS) ${ }^{(30,31)}$. A possible explanation for this discrepancy might be that an increased dietary $\mathrm{Na}$ intake enhances urinary total $\mathrm{Ca}$ excretion as seen in humans, but by augmenting urine volume, does not lead to substantially elevated urine $\mathrm{Ca}$ concentrations $^{(9,27)}$.

Overall, research indicates that the urine volume in cats can be increased successfully by feeding a high-moisture diet, as well as by increasing dietary $\mathrm{Na}$ intake. An increased $\mathrm{Na}$ intake might be used as a preventative measure for $\mathrm{CaOx}$ formation as there is no evidence that dietary $\mathrm{Na}$ induces elevated $\mathrm{Ca}$ concentrations in the urine of healthy cats, and there are no adverse long-term effects reported for this nutrient on, for example, blood pressure and kidney functioning as well ${ }^{(32,33)}$. However, the effectiveness of increased dietary $\mathrm{Na}$ intake on reducing $\mathrm{CaOx}$ urolith formation in urolith-forming cats has not been tested.

\section{Urinary oxalate}

Since oxalate forms a relatively insoluble salt with $\mathrm{Ca}$ ions at physiological $\mathrm{pH}$, an increased urinary excretion of oxalate, i.e. hyperoxaluria, can promote $\mathrm{CaOx}$ formation. It has been argued that an increase in urinary oxalate concentration promotes $\mathrm{CaOx}$ urolith formation to a greater extent than comparable increases in $\mathrm{Ca}$, as changes in urinary oxalate concentration are fifteen times as potent as equimolar changes in $\mathrm{Ca}$ concentration in effecting $\mathrm{CaOx}$ saturation ${ }^{(34,35)}$. Therefore, hyperoxaluria is generally accepted as a critical factor of $\mathrm{CaOx}$ urolithiasis $^{(36)}$. To be able to reduce urinary oxalate excretion, it is essential to understand the origin of the oxalates excreted in the urine of cats. Both the intake of dietary oxalate (exogenous oxalate) and biosynthesis of oxalate (endogenous oxalate) contribute to the amount of oxalate excreted with the urine.

Factors influencing urinary oxalate: exogenous urinary oxalates. Intake of dietary oxalate is a known factor that increases urinary oxalate excretion. The amount of dietary oxalate available for absorption in the gastrointestinal tract is dependent on the amount of free oxalate present in the diet, dietary components which can form complexes with free oxalate (for example, $\mathrm{Ca}, \mathrm{Mg}$ ) and the activity of oxalate-degrading bacteria in the gastrointestinal tract of man and animals.

In general, large amounts of oxalate are present in green leafy vegetables and bran concentrates, moderate amounts in nuts and cereals, and low amounts in dairy products, meat and fish ${ }^{(37,38)}$. The contribution of dietary oxalate intake to urinary oxalate excretion in free-roaming cats is unknown, but can be expected to be low, as the natural (carnivorous) diet of the cat is mainly composed of food/ prey items that contain low amounts of oxalate ${ }^{(39,40)}$. In contrast, omnivorous diets (for example, for humans and rats) contain moderate to high levels of oxalate, which may result in a relatively high contribution of exogenous oxalate to total urinary oxalate excretion. In humans, contributions of dietary oxalate to urinary oxalates have been reported, with estimates ranging from 25 to $68 \%{ }^{(41,42)}$. Unfortunately, no such data are available in cats.

In thirty different dry pet foods for adult small breed dogs, the oxalate content was found to range between 9.6 and $60.0 \mathrm{mg} / \mathrm{MJ} \mathrm{ME}(4-25 \mathrm{mg} / 100 \mathrm{kcal})$ with a mean of $26.3 \mathrm{mg} / \mathrm{MJ} \mathrm{ME}(11 \mathrm{mg} / 100 \mathrm{kcal})^{(43)}$. In a canned diet designed to assist in the management of LUTD in dogs, the oxalate content was $5.9 \mathrm{mg} / \mathrm{MJ} \mathrm{ME}$ $(2.5 \mathrm{mg} / 100 \mathrm{kcal})^{(44)}$. The average daily intake of oxalate (2.5-15.5 mg/kg body weight (BW) per d) in dogs fed these commercial dry diets can be considered to be relatively high compared with the average oxalate intake $\left(2-3 \mathrm{mg} / \mathrm{kg}\right.$ BW per d) by humans ${ }^{(43)}$. Stevenson et al. ${ }^{(43)}$ studied the relative effects of dietary $\mathrm{Ca}$ and oxalate on the composition of urine by feeding healthy dogs a diet supplemented with 24.0 to $60.0 \mathrm{mg}$ oxalate/MJ $(10-25 \mathrm{mg} / 100 \mathrm{kcal})$ and varying the dietary Ca contents. These authors found that the oxalate excretion inconsistently increased with a higher oxalate intake only when dietary $\mathrm{Ca}$ intake was low (molar Ca:oxalate ratio $<18$ ). With higher dietary $\mathrm{Ca}$ :oxalate ratios $(>25)$ the oxalate excretion remained low and stable, irrespective of dietary oxalate content. The variation between dogs when different oxalate levels were fed, in conjunction with a low dietary $\mathrm{Ca}$ content, was very high, with effects ranging from 0 to a $400 \%$ increase in urinary oxalate excretion. These results indicate that the contribution of dietary oxalate to urinary oxalate excretion in dogs is dependent on the dietary $\mathrm{Ca}$ content, and is expected to be low with a high $(>40)$ molar Ca:oxalate ratio in the diet.

Other factors than dietary $\mathrm{Ca}$ are also known to influence intestinal oxalate absorption. A similar role for dietary $\mathrm{Mg}$ has been found ${ }^{(45)}$. Both minerals can directly interact with oxalate to form an insoluble complex to lower the free oxalate concentration in the gastrointestinal tract ${ }^{(45)}$, resulting in a reduction in the absorption of oxalate ${ }^{(42,46,47)}$. Fat and phosphate can act as scavengers for Ca, thereby indirectly increasing the availability of oxalate for uptake by the intestine ${ }^{(48,49)}$. In addition, oxalate-degrading bacteria, such as Oxalobacter formigenes present in the intestinal tract of man and rats, are known to reduce the 
contribution of exogenous urinary oxalates to total urinary oxalates, as this bacterium uses oxalic acid (or its anion oxalate) as its sole energy source by degrading oxalic acid to formate ${ }^{(50,51)}$. O. formigenes has also been detected in the stool of cats and dogs ${ }^{(52,53)}$. Lactic acid bacteria have also been shown to degrade oxalates in vitro ${ }^{(54)}$. The impact of oxalate-degrading bacteria in the gastrointestinal tract of humans and animals on urinary oxalate excretion remains to be clarified.

Research in dogs indicates that, although canine foods contain relatively high levels of oxalate, the contribution of exogenous oxalates to the urinary oxalate excretion is expected to be of minor importance mainly due to the high molar Ca:oxalate ratio in commercial canine foods. The influence of factors other than dietary Ca that are known to affect intestinal oxalate absorption in humans is not known in dogs and cats, but is expected to be of minor importance in practice, as the dietary $\mathrm{Mg}$ content in the majority of commercial foods is approximately 10fold lower than the Ca content, and dietary $\mathrm{Ca}$ and phosphate are normally balanced. Oxalate and Ca contents of dry commercial feline diets may be expected to be in the same range as canine foods, as similar ingredients are used. This would imply that the potential contribution of exogenous oxalates to total urinary oxalate excretion by domestic cats is expected to be marginal as well, as the Ca:oxalate ratio can be expected to be high. However, the oxalate content of commercial feline foods and its contribution to urinary oxalate excretion remains to be determined in order to ascertain its relative importance.

Factors influencing urinary oxalate: endogenous urinary oxalates. Since hyperoxaluria in humans is recognised as an important risk factor for $\mathrm{CaOx}$ urolith formation, many studies (mainly in rodents) have been conducted to unravel the aetiopathogenesis of hyperoxaluria. Studies in human subjects and rodents have revealed that the largest part of the endogenous oxalate formation originates from the conversion of sugars (including glucose and fructose), amino acids (including hydroxyproline, glycine, serine, phenylalanine, tyrosine and tryptophan) and/or glycolate, ending via the metabolism of glyoxylate to oxalate. Another precursor that can give rise to oxalate is ascorbic acid, which can break down non-enzymically in urine to produce oxalate, a reaction which is accelerated at alkaline $\mathrm{pH}$. Originally it was thought that 40 to $50 \%$ of urinary oxalate was derived from the breakdown of ascorbic $\operatorname{acid}^{(42,55-57)}$. However, close scrutiny of the experimental procedures indicates that the breakdown occurred due to processing of urine at alkaline $\mathrm{pH}^{(58)}$. In cats, ascorbate has not been found to be an important dietary precursor of oxalate ${ }^{(59)}$, indicating that endogenous oxalate biosynthesis in cats relies predominately on glyoxylate metabolism.

Endogenous biosynthesis of oxalate occurs mainly in the liver ${ }^{(60)}$ and is highly dependent on the glyoxylate content in the hepatocytes (Fig. 3). Any glyoxylate that is not reduced to glycolate or transaminated to glycine is oxidised to oxalate, a reaction catalysed by cytosolic L-lactate dehydrogenase $^{(61)}$ (Fig. 3(a), step I). Since oxalate can be considered a metabolic 'end-waste-product' it will be quantitatively excreted in the urine, mainly via glomerular filtration. Oxalate excretion also occurs in the proximal tubule after a high oral oxalate $\operatorname{load}^{(62,63)}$. The most efficient way of reducing urinary endogenous oxalate excretion is to reduce the content of glyoxylate in the hepatocyte (Fig. 3). This can be achieved in two ways: by supplying less dietary precursors for glyoxylate production in the hepatocyte or by metabolic removal of glyoxylate from oxalate synthesis.

Glyoxylate removal can be achieved through the conversion into glycine, which is catalysed by serine: pyruvate aminotransferase/alanine:glyoxylate aminotransferase, also called alanine:glyoxylate aminotransferase 1 (AGT1) $^{(64)}$ (Fig. 3(a), step II). This enzyme can also convert serine into hydroxypyruvate. An essential cofactor for AGT1 is pyridoxine, or vitamin $\mathrm{B}_{6}$. A deficiency in pyridoxine can lead to a shift from glyoxylate removal through conversion into glycine, to glyoxylate oxidation to oxalate. This shift has been well documented in cats. In a study with kittens that were fed a pyridoxine-deficient diet, a significantly higher daily urinary oxalate excretion was observed $^{(65)}$.

Glyoxylate can also be converted into glycolate (Fig. 3(a), step III) via the action of the enzyme glyoxylate reductase/ hydroxypyruvate reductase (GR/HPR), a 2-hydroxy-acid dehydrogenase. GR/HPR also catalyses the reduction of hydroxypyruvate to D-glycerate (Fig. 3(a), step IV) and the oxidation of $\mathrm{D}$-glycerate to hydroxypyruvate ${ }^{(66)}$. In the human liver, GR/HPR is found predominantly in the cytosol ( $>90 \%$ ), with a small portion in the mitochondria $^{(67)}$. In cats, GR/HPR localisation has been reported to predominantly occur in the cytosol ${ }^{(68)}$.

The existence and importance of the conversions of glyoxylate into glycine and glycolate in the hepatocyte has been discovered as a result of extensive research into two severe autosomal-recessive disorders leading to mild to severe hyperoxaluria in humans. These disorders are termed primary hyperoxaluria $(\mathrm{PH})$ and two types can be distinguished. PH type I is an inherited disorder of glyoxylate metabolism arising from a deficiency in AGT1, leading to a disrupted conversion of glyoxylate into glycine (Fig. 3(a), step II). PH type II is an inherited disease caused by mutations in GR/HPR, leading to a reduced conversion of glyoxylate into glycolate (Fig. 3(a), step III) and that of hydroxypyruvate into D-glycerate (Fig. 3(a), step IV) ${ }^{(69,70)}$. PH type II patients have a limited ability to convert D-glycerate into hydroxypyruvate, resulting in most cases in an elevated concentration of L-glycerate in the urine, as metabolic removal of D-glycerate occurs via conversion into L-glycerate (Fig. 3). The reported cases of $\mathrm{PH}$ in cats ${ }^{(71,72)}$ reflect those of human $\mathrm{PH}$ type $\mathrm{II}^{(68)}$, while 


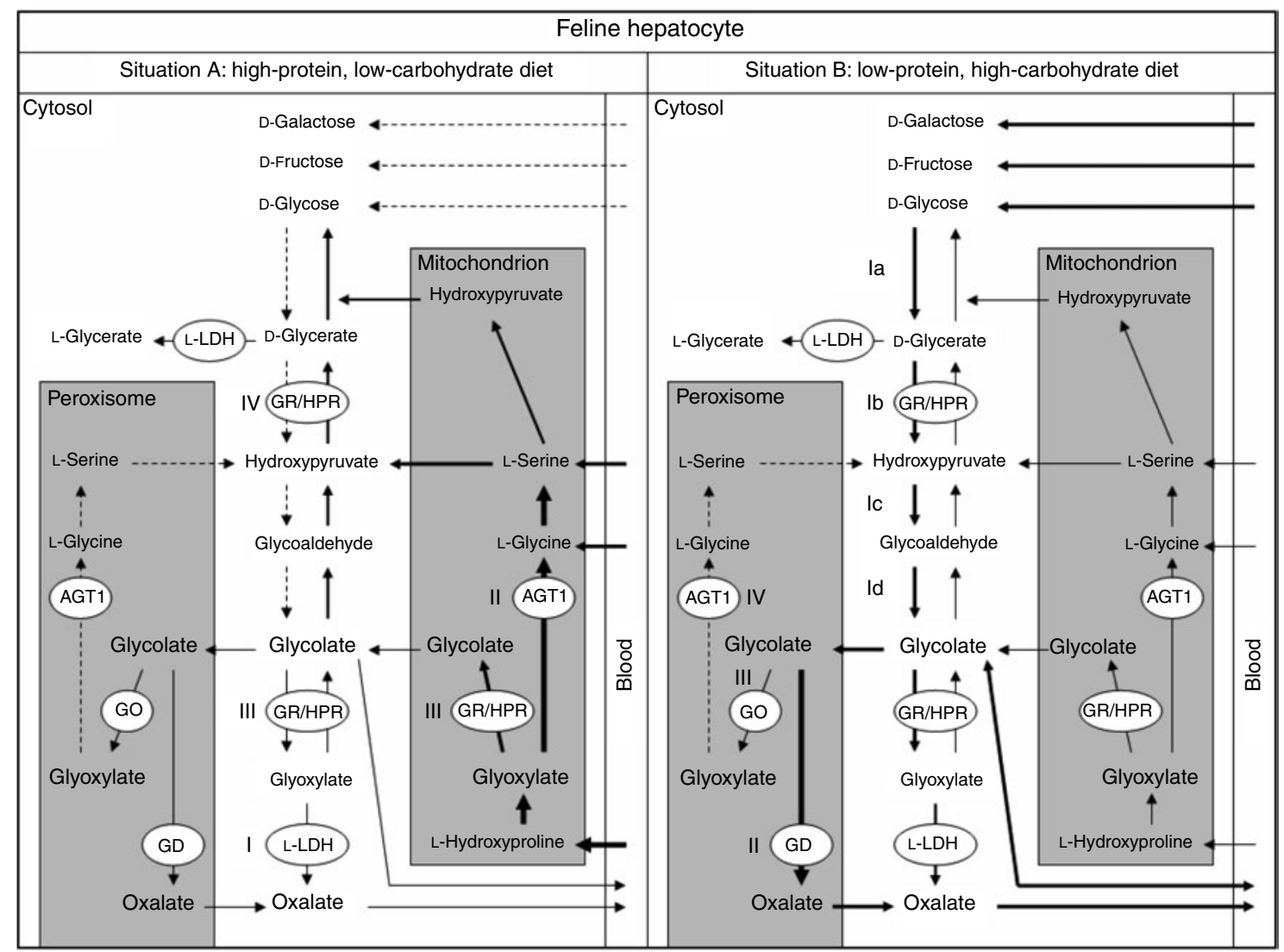

Fig. 3. Proposed metabolic pathways of de novo oxalate synthesis via glyoxylate metabolism. Major metabolic conversions that are considered prominent in the feline hepatocytes when precursors from a carnivorous and omnivorous diet are present are shown in panels A and B, respectively. Metabolic conversions expected to play a major role are indicated by thick arrows. Metabolic conversions expected to play a minor role are indicated by dashed arrows. Essential metabolic conversions in situation A are indicated with I, II, III or IV, meaning: I, conversion of glyoxylate into oxalate catalysed by cytosolic L-lactate dehydrogenase $(\mathrm{L}-\mathrm{LDH})^{(61,69)}$; II, conversion of glyoxylate into L-glycine catalysed by alanine:glyoxylate aminotransferase 1 (AGT1) ${ }^{(64,74,75,82,83,92,100,101,105)}$; III, conversion of glyoxylate into glycolate catalysed by glyoxylate reductase/hydroxypyruvate reductase (GR/HPR) ${ }^{(67,68,69,72,155,156)}$; IV, conversion of hydroxypyruvate into D-glycerate catalysed by glyoxylate reductase/hydroxypyruvate reductase ${ }^{(67,68,69,72,155,156)}$. Essential metabolic conversions in situation $B$ are indicated with la-d, $\mathrm{II}$, III and IV, meaning: Ia, conversion of cytosolic D-fructose, D-glucose and D-galactose into D-glycerate ${ }^{(86,87,89)}$; Ib, conversion of D-glycerate into hydroxypyruvate; Ic, conversion of hydroxypyruvate into glycolaldehyde ${ }^{(80)}$; Id, conversion of glycolaldehyde into glycolate ${ }^{(80)}$; II, conversion of peroxisomal glycolate into oxalate catalysed by glycolate dehydrogenase $(\mathrm{GD})^{(97)}$; III, conversion of peroxisomal glycolate into glyoxylate catalysed by glycolate oxidase (GO) ${ }^{(97)}$; IV, conversion of glyoxylate into L-glycine catalysed by alanine:glyoxylate aminotransferase $1^{(64,74,75,101,157)}$.

cases of $\mathrm{PH}$ in cats analogous to human $\mathrm{PH}$ type I are unknown.

Highly notable is the observation that the spatial localisation of AGT1 seems to be species dependent. In carnivores and insectivores, AGT1 is mainly present in mitochondria ${ }^{(73,74)}$, while in the human liver an almost exclusive peroxisomal localisation of this enzyme has been reported ${ }^{(75)}$. The mitochondrial localisation of AGT1 is seen in carnivorous and insectivorous species of different genera (mammals, birds, reptiles) ${ }^{(73)}$, indicating that AGT1 localisation in the mitochondrion might be a necessity when consuming high-protein, low-carbohydrate diets. Interestingly, the Gly170Arg in combination with the Pro11Leu mutation in the gene AGXT, encoding for AGT1, which are commonly found in human patients with PH type I, targets AGT1 to mitochondria instead of to its normal location in peroxisomes ${ }^{(75)}$, resembling the mitochondrial localisation of hepatic AGT1 in carnivores $^{(74)}$. Herbivores, such as Old World monkeys (macaques and baboons), rabbits and guinea-pigs, have most, if not all of their AGT1 located in peroxisomes ${ }^{(74)}$ Rodents (rats, mice, hamsters) and marmosets (New World monkey) have AGT1 distributed approximately equally between both organelles. The interspecies difference in intracellular localisation of hepatic AGT1 may very well be the result of dietary selection pressure during evolution ${ }^{(74)}$.

Genomic expression analyses have revealed that the adaptive shift in AGT1 targeting among species can be ascribed to the use of alternative transcription- and translation-initiation sites of the single-copy AGXT gene ${ }^{(76,77)}$. The longest transcript of AGXT, as found in cats, encodes a cleavable $\mathrm{N}$-terminal mitochondrial targeting sequence (MTS) and C-terminal peroxisomal targeting sequences for peroxisomal uptake, in which MTS is dominant over peroxisomal targeting sequences in determining the final subcellular destination of $\mathrm{AGT1}^{(76,77)}$. Species such as man and rabbits expressing AGT1 almost exclusively in peroxisomes have lost the first translation start site during evolution resulting in an MTS-lacking protein. In cats and 
other species expressing AGT1 almost exclusively in mitochondria, almost all encoded proteins contain the MTS due to the loss of the - more downstream - second transcription-initiation site ${ }^{(74,77)}$. Species in which hepatic AGT1 is roughly equally distributed between both organelles utilise both translation-initiation sites ${ }^{(78)}$.

It has been postulated that the dual localisation of AGT1 in the liver is a reflection of its dual physiological function: that is, its role in glyoxylate detoxification in peroxisomes and its role in gluconeogenesis in mitochondria ${ }^{(64,74)}$. Intraperoxisomal glyoxylate detoxification is essential in herbivores, since their diet is rich in glycolate and carbohydrates. To prevent oxidation of cytosolic glyoxylate to oxalate by L-lactate dehydrogenase (Fig. 3(a), step I), a high activity of intraperoxisomal AGT1 is required. High levels of glycolate and carbohydrates in combination with a scarcity of animal protein (containing L-hydroxyproline, glycine, serine), typically found in diets of herbivores, retard the need for directing hydroxyproline-derived glyoxylate into gluconeogenesis by conversions facilitated by AGT1 (Fig. 3(a), step II). In contrast, carnivores and insectivores are likely to have consumed a very low amount of glycolate and carbohydrates during evolution and these species have not required intensive detoxification of glyoxylate in the peroxisome. In contrast, the high animal protein and low carbohydrate content of the diet of carnivores and insectivores would clearly favour the contribution of gluconeogenesis in the mitochondrion ${ }^{(64)}$.

As stated earlier, the glyoxylate content in the hepatocyte is also dependent on certain dietary precursors. In human medicine, it has been demonstrated that a high intake of amino acids (i.e. hydroxyproline, serine, glycine, phenylalanine, tyrosine and tryptophan) ${ }^{(78-83)}$ or sugars (i.e. glucose, fructose, galactose, xylose $)^{(84-89)}$ stimulates oxalate synthesis from the intermediate product glyoxylate. Knight et al. ${ }^{(90,91)}$ showed that hydroxyproline is a potent contributor to urinary oxalates, with glycine contributing little to the endogenous production of glycolate or oxalate. In cats, the endogenous synthesis of oxalate has not been widely studied. A study by Zentek \& Schulz ${ }^{(92)}$ describes the effects of various dietary protein sources (collagen tissue, horse meat and soya isolate) on urine composition, including urinary oxalate excretion. Uptake of the (high)-protein diet with collagen as the protein source resulted in an increase in urinary oxalate excretion (2.83 (SD 0.89) $\mathrm{mg} / \mathrm{kg} \mathrm{BW}$ per d) compared with the (high)protein diets with horse meat and soya protein isolate as the protein source $(0.94(\mathrm{SD} 0.29) \mathrm{mg} / \mathrm{kg}$ BW per $\mathrm{d}$ and 1.17 ( $\mathrm{SD} 0.53) \mathrm{mg} / \mathrm{kg} \mathrm{BW}$ per $\mathrm{d}$, respectively). Since the hydroxyproline content of collagen tissue is high (about 10-13\%), mitochondrial AGT1, which converts L-hydroxyproline-derived glyoxylate into glycine (Fig. 3(a), step II), might have been saturated in the cats fed the collagen protein, leading to undesirable conversion to oxalate by L-lactate dehydrogenase (Fig. 3(a), step I), resulting in an increased urinary oxalate excretion ${ }^{(83)}$.
Besides hydroxyproline, the amino acids glycine and serine are also present in relatively high concentrations in collagen tissue ${ }^{(93)}$.

Zentek \& Schultz ${ }^{(92)}$ also investigated the effects of different dietary protein levels on daily urinary oxalate excretion. Of each protein source (collagen tissue, horse meat and soya isolate), two diets were fed, one containing a high and the other a low protein level. In the low-protein diets, protein was exchanged with rice (carbohydrate) and animal fat. Remarkably, all low-protein diets showed a consistently higher daily urinary oxalate excretion. The oxalate excretion increased approximately 5-fold (from 2.83 (SD 0.89) to 13.70 (SD 4.32) $\mathrm{mg} / \mathrm{kg}$ BW per d) when fed the low-protein diet with collagen as the protein source compared with the high-protein diet. Urinary oxalate excretion increased 4-fold when changing from highto low-protein diets using soya isolate and horse meat as a protein source (soya isolate diet from 1.17 (SD 0.53) to $4.79(\mathrm{SD} 2.73) \mathrm{mg} / \mathrm{kg} \mathrm{BW}$ per $\mathrm{d}$ and the horse meat diet from $0.94(\mathrm{SD} 0.29)$ to 3.62 (SD 2.44) $\mathrm{mg} / \mathrm{kg}$ BW per d). However, the observed increase in urinary oxalate excretion might have been the result of a concomitant high carbohydrate intake with the low-protein diets. As stated earlier, in humans sugars (i.e. glucose, fructose, galactose, xylose) are known to be a substrate for the peroxisomal glyoxylate pathway ${ }^{(84-89)}$. It is conceivable that when fed a high-carbohydrate diet, cats suffer an overload of hepatic oxalate as a consequence of a deficiency in peroxisomal AGT1 and excrete more oxalate in their urine. Although the urinary oxalate excretion was found to be unaffected in a study feeding healthy cats a dry commercial diet with a low carbohydrate content (19.1 g/MJ ME) $v$. a high carbohydrate content $(34.7 \mathrm{~g} / \mathrm{MJ} \mathrm{ME})^{(94)}$, the carbohydrate content of the low-carbohydrate diet in this study can still considered to be high compared with the carbohydrate content of the experimental diets in the study of Zentek \& Schultz ${ }^{(92)}$ (i.e. collagen tissue diets: 2.7 v. $23 \cdot 2 \mathrm{~g} / \mathrm{MJ}$ ME; soya diets $7 \cdot 1$ v. $22 \cdot 3 \mathrm{~g} / \mathrm{MJ}$ ME; horse meat diets 5.9 v. $25 \cdot 3 \mathrm{~g} / \mathrm{MJ} \mathrm{ME)}$.

A proposed metabolic pathway for the synthesis of the undesirable metabolite oxalate in cats from sugars is presented in Fig. 3(b). In this model, the sugars D-fructose, D-glucose and D-galactose are first converted to D-glycerate (Fig. 3(b), step Ia). Since the activity of fructokinase in feline liver is found to be relatively high and that of glucokinase to be low ${ }^{(95)}$, the contribution of $\mathrm{D}$-fructose compared with D-glucose is expected to be higher. D-Glycerate can subsequently be converted into glycolate via the intermediates hydroxypyruvate and glycolaldehyde (Fig. 3(b), steps Ib, Ic and Id). The sugar D-galactose ${ }^{(84)}$ can also be converted to glycolate, with only glycolaldehyde as an intermediate. The sugar xylose enters the metabolic pathway to oxalate via glycolaldehyde as well $^{(96)}$. Cytosolic glycolate may partly be directed into the peroxisomes by diffusion where glycolate will be either oxidised directly to oxalate by the enzyme glycolate 
dehydrogenase $^{(80)}$ (Fig. 3(b), step II) or converted to glyoxylate by the enzyme glycolate oxidase ${ }^{(97)}$ (Fig. 3(b), step III). In most animals, the major part of this glyoxylate will be transaminated to glycine by AGT1 (Fig. 3(b), step IV) (i.e. peroxisomal glyoxylate detoxification), but in cats, and other carnivores, most of this glyoxylate will probably be converted back to glycolate due to a deficit of AGT1 activity in the peroxisome. This surplus in glycolate will probably result in an increased conversion of glycolate to oxalate catalysed by glycolate dehydrogenase (Fig. 3(b), step II).

An additional explanation for the increase in oxalate synthesis upon feeding diets high in carbohydrate and low in protein content may be a reduction of gluconeogenesis in the liver, which results in a lower need for glycine and serine as a gluconeogenic precursor. It is conceivable that high concentrations of glycine and/or serine attenuate mitochondrial AGT1 in a negative feedback loop. This might result in an additional shift to oxalate synthesis. Collectively, it is possible that in cats a high carbohydrate intake is a potential risk factor for $\mathrm{CaOx}$ urolith formation by increasing endogenous oxalate synthesis.

The prevention of oxalate synthesis in cats by expressing AGT1 almost exclusively in the mitochondrion can be considered as one of the many enzymic adaptations as a result of their obligatory carnivorous lifestyle throughout evolution. By expressing AGT1 almost exclusively in the mitochondrion, the formed glyoxylate (mainly originating from hydroxyproline) is efficiently transaminated to glycine (Fig. 3(a), step II), which can directly be used for intramitochondrial gluconeogenesis. This enzymic adaptation appears to be part of a long list of adaptations in this species, such as cysteine dioxygenase and cysteinesulfinate decarboxylase (taurine synthesis), pyrroline5-decarboxylase and ornithine aminotransferase (citrulline synthesis), dioxygenase (retinol synthesis), glucokinase (glucose metabolism), 7-hydroxycholesterol- $\Delta 7$ reductase (25-hydroxycholesterol synthesis) and picolinic carboxylase (nicotinic acid synthesis) ${ }^{(39,98)}$.

Dietary factors influencing endogenous urinary oxalate synthesis. In cats, urinary oxalate excretion has been found to be inversely correlated with protein intake and dependent on the protein source ${ }^{(92)}$, although the inverse correlation with protein intake might be the result of a higher carbohydrate intake. In contrast, in human subjects some studies reported that urinary oxalate excretion increased with increased dietary protein intake and decreased with protein restriction ${ }^{(99,100)}$. This might be explained by the distinct subcellular AGT1 distribution in humans and cats.

AGT1 catalyses the hepatic transamination of glyoxylate, being an important precursor of oxalate, to glycine ${ }^{(101)}$. Pyridoxine, or vitamin $\mathrm{B}_{6}$, is a known cofactor for AGT1 ${ }^{(102)}$ and, as such, pyridoxine deprivation could indirectly elevate endogenous oxalate biosynthesis and, in turn, its urinary excretion ${ }^{(103-105)}$. Indeed, the daily urinary oxalate excretion was higher in kittens fed a pyridoxine-deficient diet compared with those receiving adequate amounts of pyridoxine ${ }^{(65,106)}$. Moreover, pyridoxine can act as a cofactor for various enzymes in the tricarboxylic acid cycle as well, leading to a decreased synthesis of citrate. Thus, under the condition of pyridoxine deficiency, citrate metabolism may be impaired, leading to a lower urinary citrate concentration and increased risk of precipitation with $\mathrm{CaOx}^{(103)}$. To the authors' knowledge, the effect of pyridoxine on urinary citrate excretion in cats has not been studied.

Although an excess consumption of ascorbate (i.e. vitamin C) has been associated with increased endogenous oxalate synthesis (by the non-enzymic oxidation of ascorbate to oxalate $)^{(36,107-110)}$ in humans, in healthy cats dietary supplementation with ascorbate up to $193 \mathrm{mg} / \mathrm{kg} \mathrm{did}$ not affect urinary oxalate concentrations ${ }^{(59)}$. However, only the effect of a moderate and not a high amount of ascorbate on the urinary oxalate excretion has been tested. As cats, in contrast to man, can synthesise ascorbate in sufficient amounts de novo from glucose, ascorbate is not an essential nutrient ${ }^{(111)}$. Although there is no evidence that dietary ascorbate can increase urinary oxalate levels in cats, it is generally recommended to avoid excessive amounts of dietary ascorbate. This recommendation is purely based on the results obtained in human subjects.

\section{Urinary calcium}

It goes without saying that an increase in urinary $\mathrm{Ca}$ excretion, as one of the constituents of $\mathrm{CaOx}$ uroliths, significantly contributes to $\mathrm{CaOx}$ formation. The question is whether hypercalciuria is indeed a causative factor in $\mathrm{CaOx}$ uroliths formation. In humans hypercalciuria is thought to be a risk factor for, but not necessarily the cause of, $\mathrm{CaOx}$ urolith formation ${ }^{(2)}$

One of the factors that can cause hypercalciuria is hypercalcaemia. Approximately $35 \%$ of the cats with $\mathrm{CaOx}$ uroliths also have evidence of an increase in total serum Ca concentrations ${ }^{(112)}$. On the other hand, in a study which reported the laboratory findings, clinical course, and treatment of twenty cats with idiopathic hypercalcaemia, 35\% (seven cats) had signs of urolithiasis, and in only two cats these uroliths were composed of $\mathrm{CaOx}^{(113)}$. Although hypercalcaemia is frequently seen in cats with $\mathrm{CaOx}$ urolithiasis, hypercalcaemia in itself does not seem to be a causative factor in $\mathrm{CaOx}$ formation.

Another factor that is frequently indicated as a possible cause for hypercalciuria is feeding an acidified diet. In a case report of five cats with hypercalcaemia and CaOx urolithiasis, hypercalcaemia resolved after discontinuation of urinary acidifying therapy or dietary change, or both ${ }^{(114)}$ Controlled studies in cats have confirmed that feeding acidifying diets to cats leads to increased urinary $\mathrm{Ca}$ excretion. In a long-term case-control study, feeding healthy adult cats an acidifying diet supplemented with $1.7 \%$ phosphoric 
acid, a low urine $\mathrm{pH}(\leq 6.4)$ was found, together with an increase in urinary $\mathrm{Ca}$ excretion ${ }^{(115)}$. Another study reported the same effect, with the exception that only after 1 month of feeding an acidifying diet (1.5\% ammonium chloride added), the calciuric response declined gradually (during 4 months) ${ }^{(116)}$.

Dietary factors influencing urinary calcium excretion. Conflicting results exist in the literature on the role of dietary $\mathrm{Ca}$ in inducing and resolving hypercalciuria. For decades, the prevailing consensus was that dietary Ca restriction would reduce urinary $\mathrm{Ca}$ excretion, and as such $\mathrm{CaOx}$ formation ${ }^{(9)}$. However, recent literature in humans and dogs indicates that there might be an advantage of increased dietary $\mathrm{Ca}$ intake, which is thought to be related to interactions between $\mathrm{Ca}$ and oxalate in the intestinal lumen ${ }^{(44,117)}$. When sufficient dietary $\mathrm{Ca}$ is available, complexation with oxalate occurs in the intestinal lumen, which in turn results in a reduction of intestinal absorption and renal excretion of both exogenous $\mathrm{Ca}$ and oxalate. Furthermore, a retrospective case-control study in cats revealed that consuming diets with a relatively low amount of $\mathrm{Ca}(0.23$ to $0.49 \mathrm{~g} / \mathrm{MJ} \mathrm{ME})$ had a significantly greater risk for $\mathrm{CaOx}$ urolith formation than cats that consumed higher dietary levels of $\mathrm{Ca}^{(9)}$. This association may be explained by a higher oxalate absorption from the gastrointestinal tract.

Low dietary intake of $\mathrm{P}$ may be related to an increased urinary Ca excretion due to a lower binding of Ca by phosphate ions in the gastrointestinal tract resulting in an increased $\mathrm{Ca}$ absorption ${ }^{(118)}$. An increase in urinary $\mathrm{Ca}$ excretion due to a low dietary $\mathrm{P}$ content could explain the increased risk for developing $\mathrm{CaOx}$ uroliths in cats fed diets containing a low $\mathrm{P}$ content $(0.20 \text { to } 0.42 \mathrm{~g} / \mathrm{MJ} \mathrm{ME})^{(9)}$. On the other hand, the same study indicates that diets with a high $\mathrm{P}$ content $(0.76$ to $1.13 \mathrm{~g} / \mathrm{MJ} \mathrm{ME})$ correlate with an increased risk of $\mathrm{CaOx}$ urolith formation compared with diets with moderate $\mathrm{P}$ content $(0.66$ to $0.76 \mathrm{~g} / \mathrm{MJ} \mathrm{ME})$. Excessive amounts of $\mathrm{P}$ present in the gastrointestinal tract could compete with oxalate, preventing intestinal Ca complexation with oxalate, which in turn could increase the availability of free oxalate for intestinal absorption and eventually renal excretion ${ }^{(9,119,120)}$. The precise influence of dietary $\mathrm{P}$ on hypercalcaemia and $\mathrm{CaOx}$ formation in cats remains unclear and should be further studied.

Results of a retrospective case-control study revealed that cats fed diets with relatively high $\mathrm{K}$ contents $(0.52$ to $0.77 \mathrm{~g} / \mathrm{MJ} \mathrm{ME}$ ) were less than half as likely (OR 0.45$)$ to develop $\mathrm{CaOx}$ uroliths compared with cats fed diets with low $\mathrm{K}$ contents $(0.23 \text { to } 0.38 \mathrm{~g} / \mathrm{MJ} \mathrm{ME})^{(9)}$. In cats, no studies have been conducted that may explain this relationship. However, in human subjects, studies have observed reduced $\mathrm{Ca}$ excretion after $\mathrm{K}$ supplementation ${ }^{(121,122)}$. The authors of these studies suggested that the decrease in urinary $\mathrm{Ca}$ during $\mathrm{K}$ administration may be related to the natriuretic effects of $\mathrm{K}$, resulting in extracellular fluid-volume contraction or to K-induced phosphate retention and/or suppression of 1,25-dihydroxyvitamin $\mathrm{D}_{3}$ synthesis ${ }^{(121)}$. Another explanation for the relationship of a higher $\mathrm{K}$ content with a decrease in $\mathrm{CaOx}$ formation is the alkalising effect of $\mathrm{K}$ salts, leading to a higher urine $\mathrm{pH}$ and therefore a lower potential for $\mathrm{Ca}$ and oxalate to precipitate. Whether these suggested mechanisms are effective in cats should be investigated further.

\section{Urine $\mathrm{pH}$}

Although the solubility of $\mathrm{CaOx}$ in urine is marginally influenced by $\mathrm{pH}$ of 4.5 to $7 \cdot 5$, several epidemiological studies have consistently identified acidifying diets (containing acidifying components such as phosphoric acid, ammonium chloride or D,L-methionine) as one of the most prominent risk factors for cats ${ }^{(9,10,13)}$. The influence of urine $\mathrm{pH}$ on $\mathrm{CaOx}$ formation in cats was confirmed in a study feeding urine-acidifying, basal, and alkalinising diets to cats during 12 months (resulting in urine $\mathrm{pH}$ of $6 \cdot 2(\mathrm{SD} 0 \cdot 1), 6 \cdot 8(\mathrm{SD} 0 \cdot 2)$ and $7 \cdot 2$ ( $\mathrm{SD} 0 \cdot 3$ ), respectively). Significant differences in urine saturation for $\mathrm{CaOx}$ were found: the highest saturation occurring in cats consuming the acidifying diet and the lowest saturation occurring in cats consuming the alkalinising diet ${ }^{(123)}$. Compared with cats, a less prominent association with dietary acidifying potential was found in dogs, especially when fed canned diets $^{(124)}$. It has been suggested that urine $\mathrm{pH}$ may affect the potency of $\mathrm{CaOx}$ crystallisation inhibitors, such as chondroitin sulfate and citrate ${ }^{(125)}$. Another possible explanation is that acidifying diets increase urinary $\mathrm{Ca}$ excretion. Since there is a correlation between the base excess in the food and the average urine $\mathrm{pH}^{(126-128)}$, an acidified diet induces persistent aciduria which is associated with low-grade metabolic acidosis. This metabolic acidosis induces bone mobilisation, which results in an increased urinary Ca excretion ${ }^{(115,116,129)}$. Another mechanism of acidified urine to result in elevated $\mathrm{Ca}$ excretion is by inhibition of $\mathrm{Ca}$ reabsorption in the distal renal tubule ${ }^{(114)}$. Luminal protons directly inhibit transepithelial Ca reabsorption in the kidney by altering the conformation of the Ca-selective channel TRPV5 located in the apical membrane of the distal renal tubule ${ }^{(130)}$.

Although the cause of acidosis-induced hypercalcaemia in cats has not been identified, it is possible that acidosis affects the activity of TRPV5 in osteoclasts as well, which plays a critical role in bone formation and maintenance of serum $\mathrm{Ca}^{(131)}$. From the literature it appears that a dietary-induced decrease in urine $\mathrm{pH}$ affects the $\mathrm{Ca}$ excretion in the urine of cats, although the long-term effect remains questionable (115,116). $^{\text {. }}$

As an elevated $\mathrm{Ca}$ concentration in the urine can be considered as a risk factor for $\mathrm{CaOx}$ urolith formation, it might be reasonable to assume that a decrease in urine $\mathrm{pH}$ might affect the RSS of CaOx. However, some studies have claimed no correlation between urinary $\mathrm{pH}$ and $\mathrm{CaOx} \operatorname{RSS}^{(132,133)}$. Since the RSS is thought to serve as a 
predictor of $\mathrm{CaOx}$ urolith formation ${ }^{(134)}$, these findings suggest that factors other than urine $\mathrm{pH}$ play a role in $\mathrm{CaOx}$ urolith formation as well. However, it is important to note that, although the value for urinary RSS with $\mathrm{CaOx}$ is higher in urolith-forming dogs and cats, no prospective studies are available to confirm that a high RSS value indeed correlates with increased frequency of CaOx urolith recurrence ${ }^{(28,135)}$.

Dietary factors influencing urine $\mathrm{pH}$. Dietary protein of animal origin may decrease the base excess of the diet and increase the acid intake. As described above, a high acid intake can result in an increase in urinary $\mathrm{Ca}$ excretion. It can also reduce urinary citrate excretion since protons are able to associate with citrate in the intestine and kidney ${ }^{(136)}$. This mechanism might explain why humans do have a higher risk for $\mathrm{CaOx}$ formation following the consumption of high amounts of animal protein ${ }^{(99,137)}$. In cats, however, an opposite effect has been found. In a retrospective case-control study it was demonstrated that cats fed diets containing high amounts of protein (25.1 to $33.0 \mathrm{~g} / \mathrm{MJ} \mathrm{ME}$ ) were less than half as likely (OR 0.44 ) to develop $\mathrm{CaOx}$ urolithiasis compared with cats receiving low amounts of protein $(12.4 \text { to } 18.9 \mathrm{~g} / \mathrm{MJ} \mathrm{ME})^{(9)}$. A possible explanation might be that in cats the consumption of animal protein is often accompanied by stimulated water consumption, eventually resulting in an increase in urine volume, and an increased $\mathrm{P}$ excretion without altering $\mathrm{Ca}$ excretion ${ }^{(20)}$. The observed lower oxalate excretion in healthy cats fed a high-protein diet compared with a low-protein $\operatorname{diet}^{(92)}$ might explain this association as well (Fig. 3).

The precise mechanism in which urinary $\mathrm{Mg}$ may influence $\mathrm{CaOx}$ formation is still largely unknown. Originally, $\mathrm{Mg}$ was thought to act as a mild inhibitor of $\mathrm{CaOx}$ crystallisation ${ }^{(138)}$. Another plausible explanation is that $\mathrm{Mg}$, given as alkali salts, increase the urine $\mathrm{pH}$, which in turn stimulates urinary citrate excretion by the kidney, which reduces the risk of CaOx crystal formation ${ }^{(139,140)}$.

A retrospective case-control study in cats revealed that diets with a low Mg content (22 to $43 \mathrm{mg} / \mathrm{MJ} \mathrm{ME}$ ) were associated with $\mathrm{CaOx}$ urolith formation ${ }^{(9)}$. Several studies (in other species) have reported an association between low dietary $\mathrm{Mg}$ and $\mathrm{CaOx}$ urolith formation as well ${ }^{(139,141-143)}$. In addition, in human medicine an increased dietary intake of $\mathrm{Mg}$ salts (containing citrate) is recommended in patients suffering from $\mathrm{CaOx}$ urolithia$\operatorname{sis}^{(139,144,145)}$. An additional mechanism of action is the formation of complexes between $\mathrm{Mg}$ and oxalate, thereby reducing the supersaturation with $\mathrm{CaOx}$. However, in a study with cats fed a diet with a high $\mathrm{Mg}$ concentration, despite a significant increase in urinary $\mathrm{Mg}$, no significant effect was observed regarding urinary $\mathrm{CaOx}$ crystal growth inhibition, agglomeration inhibition or solubility, compared with the base diet ${ }^{(146)}$. Interestingly, in the earlier mentioned retrospective case-control study, diets high in $\mathrm{Mg}$ content ( 86 to $336 \mathrm{mg} / \mathrm{MJ} \mathrm{ME}$ ) were associated with a higher risk for $\mathrm{CaOx}$ urolith formation compared with diets with a moderate $\mathrm{Mg}$ content (43-86 mg/MJ $\mathrm{ME})^{(9)}$. An explanation might be that in cats the contribution of dietary oxalate to urinary oxalate excretion is less prominent and therefore complexation of oxalate in the gastrointestinal tract by $\mathrm{Mg}$ less effective. Moreover, in cats there is no evidence that hypocitrauria is a risk factor for $\mathrm{CaOx}$ urolith formation.

\section{Urinary citrate}

Citrate synthesised by the kidney or derived from the diet is one of the most abundant organic anions in urine and has two main functions. First, it prevents alkaline-induced calcium phosphate stone formation by permitting base excretion without raising urine $\mathrm{pH}$. Second, urinary citrate acts as a chelator of $\mathrm{Ca}$ and is therefore considered to be the best natural inhibitor of $\mathrm{CaOx}$ urolith formation ${ }^{(147)}$ The higher the citrate concentration in the urine, the less $\mathrm{Ca}$ is available to form CaOx crystals. As a consequence, a deficiency of urinary citrate caused by renal or gastrointestinal disorders is often seen in humans with $\mathrm{CaOx}$ stone disease $\mathrm{e}^{(148,149)}$. However, there is no evidence that hypocitrauria is a risk factor for $\mathrm{CaOx}$ urolith formation in cats. In dogs with $\mathrm{CaOx}$ urolithiasis, no hypocitrauria was reported ${ }^{(150)}$

In order to increase the citrate concentration in the urine, potassium or sodium citrate is added to the majority of the $\mathrm{CaOx}$ urolithiasis therapeutic diets. However, there have been no studies in cats investigating the effects of dietary citrate addition on citrate concentrations in the urine or the formation of $\mathrm{CaOx}$. In healthy dogs, supplementation of dietary potassium citrate did not result in a consistent increase in urinary citrate excretion ${ }^{(151)}$. In this study, only a small, but not significant, increase in urine $\mathrm{pH}$ was observed. This increase in urine $\mathrm{pH}$ might be beneficial, although the influence of the urine acidity on $\mathrm{CaOx}$ formation remains questionable.

\section{Urinary glycosaminoglycans}

GAG comprise another class of components affecting stone formation. They can act in two ways: GAG, chondroitin sulfate and heparin sulfate are freely excreted in the urine and can inhibit the growth of $\mathrm{CaOx}$ crystals. Secondly, GAG are part of the extracellular matrix and can cover the inner wall of the bladder to form a defence against microbial and crystal adherence ${ }^{(152)}$. In cats with FIC, compared with healthy cats, a lower urinary GAG excretion has been detected, indicating that the defence against microbial and crystal adherence and inhibition of $\mathrm{CaOx}$ growth is decreased ${ }^{(153)}$. Oral supplementation of GAG in order to increase the free GAG concentration in urine has been shown to have a moderate to significant beneficial effect in humans with interstitial and radial cystitis ${ }^{(154)}$. In a study where oral glucosamine supplementation (i.e. $125 \mathrm{mg} N$-acetyl glucosamine) was compared with a 
placebo control group in order to manage cats with FIC, no significant difference in urinary GAG concentration between the two groups was observed ${ }^{(17)}$. Surprisingly, the majority of the cats receiving the $N$-acetyl glucosamine did improve clinically, as was also the case for cats in the placebo group. According to Gunn-Moore \& Shenoy ${ }^{(17)}$, the improvement in both groups can be explained by the significant decrease in urine specific gravity that was found in about $90 \%$ of the subjects (of both treatment and placebo groups). It is likely that this positive effect was due to the fact that the owners decided to feed their cats more moist food during this study and not due to the $N$-acetyl glucosamine treatment.

\section{Conclusions}

Most of the dietary modifications to reduce $\mathrm{CaOx}$ urolith formation in cats and dogs are mainly based on data from epidemiological studies in these species and clinical studies in human subjects and rodents. Controlled studies designed to evaluate the efficacy of these dietary modifications in cats are scarce. To be able to improve the preventative measures (i.e. dietary modifications) against $\mathrm{CaOx}$ urolithiasis in cats, it is important to study the aetiopathogenesis of $\mathrm{CaOx}$ urolithiasis.

In contrast to human medicine, dietary modifications to decrease endogenous oxalate synthesis have hardly been studied in cats and future focus should examine the origin of urinary oxalate in cats, as a representative of the carnivores. The exclusive mitochondrial localisation of AGT1 in cats conforms to the notion that obligate carnivores, including domestic cats, are adapted to their natural diet, i.e. eating small mammals, containing high levels of animal protein, low levels of carbohydrate and glycolate. The observation that most commercial cat foods contain relatively high amounts of carbohydrates, often at the expense of animal protein, raises the question whether the consumption of these diets increases endogenous oxalate synthesis and in consequence the risk of $\mathrm{CaOx}$ urolithiasis. In addition, the contribution of exogenous oxalates to urinary oxalate excretion is unknown in cats as well. Knowledge about the dietary oxalate content in commercial feline diets, which is expected to be higher than in their natural diet, is essential in order to determine the contribution of exogenous oxalates in urinary oxalate excretion.

In-depth knowledge of feline endogenous oxalate metabolism and dietary oxalate absorption will provide a better understanding of the sharp increase in $\mathrm{CaOx}$ urolith prevalence in cats reported over the last few decades and provide new insights for preventative strategies. Also, based on the fact that in many human PH type I patients AGT1 is mistargeted to the mitochondria, mimicking the subcellular AGT1 distribution of cats, the cat might be a perfect research object to study endogenous oxalate synthesis in this genetic disorder.

\section{Acknowledgements}

This research received no specific grant from any funding agency in the public, commercial or not for-profit sectors.

Fig. 1 is reprinted from Osborne et al. ${ }^{(1)}$ with permission of Elsevier.

All authors contributed fundamentally to the present study. J. C. D. contributed to all facets, including literature study, scientific interpretation and manuscript preparation. E. A. P. contributed to scientific interpretation and overall manuscript preparation. J. v. B. and W. H. H. both added valuable scientific knowledge to the present review, and contributed to improve readability and layout of the manuscript.

There are no conflicts of interest.

\section{References}

1. Osborne CA, Lulich JP, Kruger JM, et al. (2009) Analysis of 451,891 canine uroliths, feline uroliths, and feline urethral plugs from 1981 to 2007: perspectives from the Minnesota Urolith Center. Vet Clin North Am Small Anim Pract 39, 183-197.

2. Bartges JW, Kirk C \& Lane IF (2004) Update: management of calcium oxalate uroliths in dogs and cats. Vet Clin North Am Small Anim Pract 34, 969-987.

3. Gerber B, Boretti FS, Kley S, et al. (2005) Evaluation of clinical signs and causes of lower urinary tract disease in European cats. J Small Anim Pract 46, 571-577.

4. Lund EM, Armstrong PJ, Kirk CA, et al. (1999) Health status and population characteristics of dogs and cats examined at private veterinary practices in the United States. $J$ Am Vet Med Assoc 214, 1336-1341.

5. Bartges JW \& Kirk CA (2006) Nutrition and lower urinary tract disease in cats. Vet Clin North Am Small Anim Pract 36, 1361-1376.

6. Picavet P, Detilleux J, Verschuren S, et al. (2007) Analysis of 4495 canine and feline uroliths in the Benelux. A retrospective study: 1994-2004. J Anim Physiol Anim Nutr (Berl) 91 , 247-251.

7. Buffington CA \& Chew DJ (1999) Calcium oxalate urolithiasis in cats. J Endourol 13, 659-663.

8. Buffington CA \& Chew DJ (1998) Effects of diet on cats with non-obstructive lower urinary tract disease: a review. J Anim Physiol Anim Nutr (Berl) 80, 120-127.

9. Lekcharoensuk C, Osborne CA, Lulich JP, et al. (2001) Association between dietary factors and calcium oxalate and magnesium ammonium phosphate urolithiasis in cats. $J$ Am Vet Med Assoc 219, 1228-1237.

10. Kirk CA, Ling GV, Franti CE, et al. (1995) Evaluation of factors associated with development of calcium oxalate urolithiasis in cats. J Am Vet Med Assoc 207, 1429-1434.

11. Lulich JP \& Osborne CA (2007) Feline urolithiasis: understanding the shift in urolith type. In 2007 Nestle Purina Nutrition Forum, pp. 54-59. http://www.purina.vet. breederclub.it/eventivnn/07\%20Forum\%20Proceedings.pdf (accessed 4 January 2011).

12. Lekcharoensuk C, Lulich JP, Osborne CA, et al. (2000) Association between patient-related factors and risk of calcium oxalate and magnesium ammonium phosphate urolithiasis in cats. J Am Vet Med Assoc 217, 520-525.

13. Thumchai R, Lulich J, Osborne CA, et al. (1996) Epizootiologic evaluation of urolithiasis in cats: 3,498 cases (1982-1992). J Am Vet Med Assoc 208, 547-551. 
14. Markwell PJ, Buffington CT \& Smith BH (1998) The effect of diet on lower urinary tract diseases in cats. J Nutr 128, 2753S-2757S.

15. Gaskell GC (1989) The role of fluid in the feline urological syndrome. In Nutrition of the Dog and Cat, pp. 353-356 [JPW Rivers and IH Burger, editors]. Cambridge: Cambridge University Press.

16. Burger IH \& Smith PM (1987) Effects of diet on the urine characteristics of the cat. In Nutrition, Malnutrition and Dietetics in the Dog and Cat: Proceedings of an International Symposium, pp. 71-73 [ATB Edney, editor]. London: British Veterinary Association.

17. Gunn-Moore DA \& Shenoy CM (2004) Oral glucosamine and the management of feline idiopathic cystitis. $J$ Feline Med Surg 6, 219-225.

18. Buffington CA (1994) Lower urinary tract disease in cats new problems, new paradigms. J Nutr 124, 2643S-2651S.

19. Funaba M, Yamate T, Hashida Y, et al. (2003) Effects of a high-protein diet versus dietary supplementation with ammonium chloride on struvite crystal formation in urine of clinically normal cats. Am J Vet Res 64, 1059-1064.

20. Funaba M, Hashimoto M, Yamanaka C, et al. (1996) Effects of a high-protein diet on mineral metabolism and struvite activity product in clinically normal cats. Am J Vet Res 57, 1726-1732.

21. Borghi L, Meschi T, Schianchi T, et al. (1999) Urine volume: stone risk factor and preventive measure. Nephron 81, Suppl. 1, 31-37.

22. Chandler ML (2008) Pet food safety: sodium in pet foods. Top Companion Anim Med 23, 148-153.

23. Castenmiller JJ, Mensink RP, van der Heijden L, et al. (1985) The effect of dietary sodium on urinary calcium and potassium excretion in normotensive men with different calcium intakes. Am J Clin Nutr 41, 52-60.

24. Kok DJ, Iestra JA, Doorenbos CJ, et al. (1990) The effect of dietary excesses in animal protein and sodium on the composition and the crystallization kinetics of calcium oxalate monohydrate in urines of healthy men. J Clin Endocrinol Metab 71, 861-867.

25. Sakhaee K, Harvey JA, Padalino PK, et al. (1993) The potential role of salt abuse on the risk for kidney stone formation. J Urol 150, 310-312.

26. Massey LK \& Whiting SJ (1996) Dietary salt, urinary calcium, and bone loss. J Bone Miner Res 11, 731-736.

27. Biourge V, Devois C, Morice G, et al. (2001) Increased dietary $\mathrm{NaCl}$ significantly increases urine volume but does not increase urinary calcium oxalate supersaturation in healthy cats. J Vet Intern Med, 301.

28. Lulich JP, Osborne CA \& Sanderson SL (2005) Effects of dietary supplementation with sodium chloride on urinary relative supersaturation with calcium oxalate in healthy dogs. Am J Vet Res 66, 319-324.

29. Stevenson AE, Hynds WK \& Markwell PJ (2003) Effect of dietary moisture and sodium content on urine composition and calcium oxalate relative supersaturation in healthy miniature schnauzers and labrador retrievers. Res Vet Sci 74, 145-151.

30. Hawthorne AJ \& Markwell PJ (2004) Dietary sodium promotes increased water intake and urine volume in cats. J Nutr 134, 2128S-2129S.

31. Tournier C, Aladenise S, Vialle S, et al. (2006) The effect of dietary sodium on urine composition and calcium oxalate relative supersaturation in healthy cats. In Proceedings of the 10th International Congress of ESVCN, p. 189. http:// www.royal-canin.de/fileadmin/downloads/VMM_Na_and_ CaOx_ESVCN_2006_poster.pdf (accessed 4 January 2011).

32. Xu H, Laflamme DP \& Long GL (2009) Effects of dietary sodium chloride on health parameters in mature cats. J Feline Med Surg 11, 435-441.
33. Luckschander N, Iben C, Hosgood G, et al. (2004) Dietary $\mathrm{NaCl}$ does not affect blood pressure in healthy cats. $J$ Vet Intern Med 18, 463-467.

34. Borsatti A (1991) Calcium oxalate nephrolithiasis: defective oxalate transport. Kidney Int 39, 1283-1298.

35. Finlayson B (1978) Physicochemical aspects of urolithiasis Kidney Int 13, 344-360.

36. Chai W, Liebman M, Kynast-Gales S, et al. (2004) Oxalate absorption and endogenous oxalate synthesis from ascorbate in calcium oxalate stone formers and non-stone formers. Am J Kidney Dis 44, 1060-1069.

37. Massey LK (2007) Food oxalate: factors affecting measurement, biological variation, and bioavailability. J Am Diet Assoc 107, 1191-1194.

38. Siener R, Honow R, Voss S, et al. (2006) Oxalate content of cereals and cereal products. J Agric Food Chem 54, 3008-3011.

39. Committee on Examining the Safety of Supplements for Horses, Dogs and Cats; National Research Council (2009) Factors affecting animal dietary supplement safety; section Biological factors affecting animal dietary supplement safety/natural diet. In Safety of Dietary Supplements for Horses, Dogs and Cats, pp. 36-37. Washington, DC: The National Academies Press.

40. Plantinga EA, Bosch G \& Hendriks WH (2010) Feline paleolithic nutrition: a consideration of its nature and its implications for digestive physiology. Br J Nutr (In the Press).

41. von Unruh GE, Voss S \& Sauerbruch T (2003) Reference range for gastrointestinal oxalate absorption measured with a standardized $\left[{ }^{13} \mathrm{C}_{2}\right]$ oxalate absorption test. J Urol 169, 687-690.

42. Holmes RP, Goodman HO \& Assimos DG (2001) Contribution of dietary oxalate to urinary oxalate excretion. Kidney Int 59, 270-276.

43. Stevenson AE, Hynds WK \& Markwell PJ (2003) The relative effects of supplemental dietary calcium and oxalate on urine composition and calcium oxalate relative supersaturation in healthy adult dogs. Res Vet Sci 75, 33-41.

44. Stevenson AE, Blackburn JM, Markwell PJ, et al. (2004) Nutrient intake and urine composition in calcium oxalate stone-forming dogs: comparison with healthy dogs and impact of dietary modification. Vet Ther 5, 218-231.

45. Morozumi M, Hossain RZ, Yamakawa K, et al. (2006) Gastrointestinal oxalic acid absorption in calcium-treated rats. Urol Res 34, 168-172.

46. Liebman M \& Chai W (1997) Effect of dietary calcium on urinary oxalate excretion after oxalate loads. Am J Clin Nutr 65, 1453-1459.

47. Liebman M \& Costa G (2000) Effects of calcium and magnesium on urinary oxalate excretion after oxalate loads. J Urol 163, 1565-1569.

48. Masai M, Ito H \& Kotake T (1995) Effect of dietary intake on urinary oxalate excretion in calcium renal stone formers. Br J Urol 76, 692-696.

49. Naya Y, Ito H, Masai M, et al. (2002) Association of dietary fatty acids with urinary oxalate excretion in calcium oxalate stone-formers in their fourth decade. BJU Int $\mathbf{8 9}$, 842-846.

50. Sidhu H, Allison MJ, Chow JM, et al. (2001) Rapid reversal of hyperoxaluria in a rat model after probiotic administration of Oxalobacter formigenes. J Urol 166, 1487-1491.

51. Troxel SA, Sidhu H, Kaul P, et al. (2003) Intestinal Oxalobacter formigenes colonization in calcium oxalate stone formers and its relation to urinary oxalate. J Endourol 17, 173-176.

52. Weese JS \& Palmer A (2009) Presence of Oxalobacter formigenes in the stool of healthy dogs. Vet Microbiol 137, $412-413$. 
53. Weese JS, Weese HE \& Rousseau J (2009) Identification of Oxalobacter formigenes in the faeces of healthy cats. Lett Appl Microbiol 49, 800-802.

54. Weese JS, Weese HE, Yuricek L, et al. (2004) Oxalate degradation by intestinal lactic acid bacteria in dogs and cats. Vet Microbiol 101, 161-166.

55. Lulich JP, Osborne CA, Thumchai R, et al. (1999) Epidemiology of canine calcium oxalate uroliths. Identifying risk factors. Vet Clin North Am Small Anim Pract 29, 113-122, xi.

56. Williams HE (1978) Oxalic acid and the hyperoxaluric syndromes. Kidney Int 13, 410-417.

57. Ogawa Y, Miyazato $T \&$ \& Hatano $T$ (2000) Oxalate and urinary stones. World J Surg 24, 1154-1159.

58. Holmes RP, Knight J \& Assimos DG (2007) Origin of urinary oxalate. Renal Stone Dis 900, 176-182.

59. Yu S \& Gross K (2005) Moderate dietary vitamin C supplement does not affect urinary oxalate concentrations in cats. J Anim Physiol Anim Nutr 89, 428-429.

60. Farinelli MP \& Richardson KE (1983) Oxalate synthesis from $\left[{ }^{14} \mathrm{C}_{1}\right]$ glycollate and $\left[{ }^{14} \mathrm{C}_{1}\right]$ glyoxylate in the hepatectomized rat. Biochim Biophys Acta 757, 8-14.

61. Behnam JT, Williams EL, Brink S, et al. (2006) Reconstruction of human hepatocyte glyoxylate metabolic pathways in stably transformed Chinese-hamster ovary cells. Biochem J 394, 409-416.

62. Holmes RP, Ambrosius WT \& Assimos DG (2005) Dietary oxalate loads and renal oxalate handling. J Urol 174, 943-947.

63. Knight J, Holmes RP \& Assimos DG (2007) Intestinal and renal handling of oxalate loads in normal individuals and stone formers. Urol Res 35, 111-117.

64. Danpure CJ, Guttridge KM, Fryer P, et al. (1990) Subcellular distribution of hepatic alanine:glyoxylate aminotransferase in various mammalian species. J Cell Sci 97, 669-678.

65. Bai SC, Sampson DA, Morris JG, et al. (1989) Vitamin B-6 requirement of growing kittens. J Nutr 119, 1020-1027.

66. Williams HE \& Smith LH Jr (1968) L-Glyceric aciduria. A new genetic variant of primary hyperoxaluria. $N$ Engl J Med $\mathbf{2 7 8}$, 233-238.

67. Mistry J, Danpure CJ \& Chalmers RA (1988) Hepatic D-glycerate dehydrogenase and glyoxylate reductase deficiency in primary hyperoxaluria type 2 . Biochem Soc Trans 16, 626-627.

68. Danpure CJ, Jennings PR, Mistry J, et al. (1989) Enzymological characterization of a feline analogue of primary hyperoxaluria type 2: a model for the human disease. J Inherit Metab Dis 12, 403-414.

69. Mdluli K, Booth MP, Brady RL, et al. (2005) A preliminary account of the properties of recombinant human glyoxylate reductase (GRHPR), LDHA and LDHB with glyoxylate, and their potential roles in its metabolism. Biochim Biophys Acta 1753, 209-216.

70. Cramer SD, Ferree PM, Lin K, et al. (1999) The gene encoding hydroxypyruvate reductase (GRHPR) is mutated in patients with primary hyperoxaluria type II. Hum $\mathrm{Mol}$ Genet 8, 2063-2069.

71. De Lorenzi D, Bernardini M \& Pumarola M (2005) Primary hyperoxaluria (L-glyceric aciduria) in a cat. J Feline Med Surg 7, 357-361.

72. McKerrell RE, Blakemore WF, Heath MF, et al. (1989) Primary hyperoxaluria (L-glyceric aciduria) in the cat: a newly recognised inherited disease. Vet Rec 125, 31-34.

73. Danpure CJ, Fryer P, Jennings PR, et al. (1994) Evolution of alanine:glyoxylate aminotransferase 1 peroxisomal and mitochondrial targeting. A survey of its subcellular distribution in the livers of various representatives of the classes Mammalia, Aves and Amphibia. Eur J Cell Biol 64, 295-313.
74. Lumb MJ, Purdue PE \& Danpure CJ (1994) Molecular evolution of alanine/glyoxylate aminotransferase 1 intracellular targeting. Analysis of the feline gene. Eur J Biochem 221, 53-62.

75. Danpure CJ (2006) Primary hyperoxaluria type 1: AGT mistargeting highlights the fundamental differences between the peroxisomal and mitochondrial protein import pathways. Biochim Biophys Acta 1763, 1776-1784.

76. Oatey PB, Lumb MJ \& Danpure CJ (1996) Molecular basis of the variable mitochondrial and peroxisomal localisation of alanine-glyoxylate aminotransferase. Eur $J$ Biochem 241, 374-385.

77. Birdsey GM, Lewin J, Cunningham AA, et al. (2004) Differential enzyme targeting as an evolutionary adaptation to herbivory in carnivora. Mol Biol Evol 21, 632-646.

78. Purdue PE, Lumb MJ \& Danpure CJ (1992) Molecular evolution of alanine/glyoxylate aminotransferase 1 intracellular targeting. Analysis of the marmoset and rabbit genes. Eur J Biochem 207, 757-766.

79. Holmes RP \& Assimos DG (1998) Glyoxylate synthesis, and its modulation and influence on oxalate synthesis. $J$ Urol 160, 1617-1624.

80. Gambardella RL \& Richardson KE (1978) The formation of oxalate from hydroxypyruvate, serine, glycolate and glyoxylate in the rat. Biochim Biophys Acta 544, 315-328.

81. Gambardella RL \& Richardson KE (1977) The pathways of oxalate formation from phenylalanine, tyrosine, tryptophan and ascorbic acid in the rat. Biochim Biophys Acta $\mathbf{4 9 9}$, $156-168$.

82. Ribaya JD \& Gershoff SN (1981) Effects of hydroxyproline and vitamin B-6 on oxalate synthesis in rats. J Nutr 111, $1231-1239$.

83. Takayama T, Fujita K, Suzuki K, et al. (2003) Control of oxalate formation from L-hydroxyproline in liver mitochondria. J Am Soc Nephrol 14, 939-946.

84. Ribaya-Mercado JD \& Gershoff SN (1984) Effects of sugars and vitamin B-6 deficiency on oxalate synthesis in rats. J Nutr 114, 1447-1453.

85. Nguyen UN, Dumoulin G, Henriet MT, et al. (1998) Aspartame ingestion increases urinary calcium, but not oxalate excretion, in healthy subjects. J Clin Endocrinol Metab 83, $165-168$.

86. Nguyen NU, Dumoulin G, Henriet MT, et al. (1998) Effects of i.v. insulin bolus on urinary calcium and oxalate excretion in healthy subjects. Horm Metab Res 30, 222-226.

87. Nguyen NU, Dumoulin G, Wolf JP, et al. (1989) Urinary calcium and oxalate excretion during oral fructose or glucose load in man. Horm Metab Res 21, 96-99.

88. Nguyen NU, Dumoulin G, Henriet MT, et al. (1993) Carbohydrate metabolism and urinary excretion of calcium and oxalate after ingestion of polyol sweeteners. J Clin Endocrinol Metab 77, 388-392.

89. Nguyen NU, Dumoulin G, Henriet MT, et al. (1995) Increase in urinary calcium and oxalate after fructose infusion. Horm Metab Res 27, 155-158.

90. Knight J, Jiang J, Assimos DG, et al. (2006) Hydroxyproline ingestion and urinary oxalate and glycolate excretion. Kidney Int 70, 1929-1934.

91. Knight J, Easter LH, Neiberg R, et al. (2009) Increased protein intake on controlled oxalate diets does not increase urinary oxalate excretion. Urol Res 37, 63-68.

92. Zentek J \& Schulz A (2004) Urinary composition of cats is affected by the source of dietary protein. $J$ Nutr $\mathbf{1 3 4}$, 2162S-2165s

93. Laser Reutersward A, Asp NG \& Bjork I (1985) Protein digestibility of pigskin and bovine tendon in rats. $J$ Food Technol 20, 745-752. 
94. Mustillo M, Bartges JW, Kirk CA, et al. (2008) Influence of a low carbohydrate, dry formulated diet on urinary saturation for calcium oxalate and struvite in healthy adult female cats. ACVIM Forum 2008. J Vet Intern Med 22, 733.

95. Tanaka A, Inoue A, Takeguchi A, et al. (2005) Comparison of expression of glucokinase gene and activities of enzymes related to glucose metabolism in livers between dog and cat. Vet Res Commun 29, 477-485.

96. Rofe AM, Thomas DW, Edwards RG, et al. (1977) $\left({ }^{14} \mathrm{C}\right)$ Oxalate synthesis from $\left(\mathrm{U}_{-}{ }^{14} \mathrm{C}\right) \mathrm{xylitol}$ : in vivo and in vitro studies. Biochem Med 18, 440-451.

97. Yanagawa M, Maeda-Nakai E, Yamakawa K, et al. (1990) The formation of oxalate from glycolate in rat and human liver. Biochim Biophys Acta 1036, 24-33.

98. Morris JG (2002) Idiosyncratic nutrient requirements for cats appear to be diet-induced evolutionary adaptations. Nutr Res Rev 15, 153-168.

99. Curhan GC, Willett WC, Rimm EB, et al. (1993) A prospective study of dietary calcium and other nutrients and the risk of symptomatic kidney stones. N Engl J Med 328, 833-838.

100. Nguyen QV, Kalin A, Drouve U, et al. (2001) Sensitivity to meat protein intake and hyperoxaluria in idiopathic calcium stone formers. Kidney Int 59, 2273-2281.

101. Noguchi T, Okuno E, Takada Y, et al. (1978) Characteristics of hepatic alanine-glyoxylate aminotransferase in different mammalian species. Biochem J 169, 113-122.

102. Takada Y, Mori $T$ \& Noguchi $T$ (1984) The effect of vitamin $\mathrm{B}_{6}$ deficiency on alanine:glyoxylate aminotransferase isoenzymes in rat liver. Arch Biochem Biophys 229, 1-6.

103. Teerajetgul Y, Hossain RZ, Yamakawa K, et al. (2007) Oxalate synthesis from hydroxypyruvate in vitamin- $\mathrm{B}_{6}$-deficient rats. Urol Res 35, 173-178.

104. Nishijima S, Sugaya K, Morozumi M, et al. (2003) Hepatic alanine-glyoxylate aminotransferase activity and oxalate metabolism in vitamin $\mathrm{B}_{6}$ deficient rats. J Urol 169, 683-686.

105. Ogawa Y, Hossain RZ, Ogawa T, et al. (2007) Vitamin $B_{6}$ deficiency augments endogenous oxalogenesis after intravenous L-hydroxyproline loading in rats. Urol Res 35, $15-21$.

106. Bai SC, Sampson DA, Morris JG, et al. (1991) The level of dietary protein affects the vitamin B-6 requirement of cats. J Nutr 121, 1054-1061.

107. Auer BL, Auer D \& Rodgers AL (1998) Relative hyperoxaluria, crystalluria and haematuria after megadose ingestion of vitamin C. Eur J Clin Invest 28, 695-700.

108. Moyad MA, Combs MA, Crowley DC, et al. (2009) Vitamin C with metabolites reduce oxalate levels compared to ascorbic acid: a preliminary and novel clinical urologic finding. Urol Nurs 29, 95-102.

109. Massey LK, Liebman M \& Kynast-Gales SA (2005) Ascorbate increases human oxaluria and kidney stone risk. $J$ Nutr 135, 1673-1677.

110. Baxmann AC, De O G Mendonça C \& Heilberg IP (2003) Effect of vitamin $\mathrm{C}$ supplements on urinary oxalate and $\mathrm{pH}$ in calcium stone-forming patients. Kidney Int $\mathbf{6 3}$, 1066-1071.

111. Subcommittee on Dog and Cat Nutrition, Committee on Animal Nutrition \& National Research Council (2006) Vitamins; section Ascorbic acid. In Nutrient Requirements of Dogs and Cats, pp. 234-235. Washington, DC: The National Academies Press.

112. Osborne CA, Lulich JP, Thumchai R, et al. (1996) Feline urolithiasis. Etiology and pathophysiology. Vet Clin North Am Small Anim Pract 26, 217-232.

113. Midkiff AM, Chew DJ, Randolph JF, et al. (2000) Idiopathic hypercalcemia in cats. $J$ Vet Intern Med 14, 619-626.
114. McClain HM, Barsanti JA \& Bartges JW (1999) Hypercalcemia and calcium oxalate urolithiasis in cats: a report of five cases. J Am Anim Hosp Assoc 35, 297-301.

115. Fettman MJ, Coble JM, Hamar DW, et al. (1992) Effect of dietary phosphoric acid supplementation on acid-base balance and mineral and bone metabolism in adult cats. Am J Vet Res 53, 2125-2135.

116. Ching SV, Fettman MJ, Hamar DW, et al. (1989) The effect of chronic dietary acidification using ammonium chloride on acid-base and mineral metabolism in the adult cat. J Nutr 119, 902-915.

117. Penniston KL \& Nakada SY (2009) Effect of dietary changes on urinary oxalate excretion and calcium oxalate supersaturation in patients with hyperoxaluric stone formation. Urology 73, 484-489.

118. Pastoor FJ, Van't Klooster AT, Mathot JN, et al. (1995) Increasing phosphorus intake reduces urinary concentrations of magnesium and calcium in adult ovariectomized cats fed purified diets. J Nutr 125, 1334-1341.

119. Curhan GC, Willett WC, Speizer FE, et al. (1997) Comparison of dietary calcium with supplemental calcium and other nutrients as factors affecting the risk for kidney stones in women. Ann Intern Med 126, 497-504.

120. Bushinsky DA, Bashir MA, Riordon DR, et al. (1999) Increased dietary oxalate does not increase urinary calcium oxalate saturation in hypercalciuric rats. Kidney Int $\mathbf{5 5}$, 602-612.

121. Lemann J Jr, Pleuss JA \& Gray RW (1993) Potassium causes calcium retention in healthy adults. $J$ Nutr $\mathbf{1 2 3}$, $1623-1626$.

122. Lemann J Jr, Pleuss JA, Gray RW, et al. (1991) Potassium administration reduces and potassium deprivation increases urinary calcium excretion in healthy adults [corrected]. Kidney Int 39, 973-983.

123. Bartges JW, Kirk CA \& Moyers T (2004) Influence of alkalinization and acidification on urine saturation with calcium oxalate and struvite and bone mineral density in healthy cats. Urol Res 32, 172.

124. Lekcharoensuk C, Osborne CA, Lulich JP, et al. (2002) Associations between dry dietary factors and canine calcium oxalate uroliths. Am J Vet Res 63, 330-337.

125. Tiselius HG (1981) The effect of $\mathrm{pH}$ on the urinary inhibition of calcium oxalate crystal growth. Br J Urol $\mathbf{5 3}$ 470-474.

126. Kienzle E, Schuknecht A \& Meyer H (1991) Influence of food composition on the urine $\mathrm{pH}$ in cats. $J$ Nutr $\mathbf{1 2 1}$, S87-S88.

127. Kienzle E \& Wilms-Eilers S (1994) Struvite diet in cats: effect of ammonium chloride and carbonates on acid base balance of cats. J Nutr 124, 2652S-2659S.

128. Wagner E, Keusch C \& Iben C (2006) Influence of the feed base excess on urine parameters in cats. J Anim Physiol Anim Nutr (Berl) 90, 19-24.

129. Dow SW, Fettman MJ, Smith KR, et al. (1990) Effects of dietary acidification and potassium depletion on acidbase balance, mineral metabolism and renal function in adult cats. $J$ Nutr 120, 569-578.

130. Yeh BI, Kim YK, Jabbar W, et al. (2005) Conformational changes of pore helix coupled to gating of TRPV5 by protons. EMBO J 24, 3224-3234.

131. van der Eerden BC, Hoenderop JG, de Vries TJ, et al. (2005) The epithelial $\mathrm{Ca}^{2+}$ channel TRPV5 is essential for proper osteoclastic bone resorption. Proc Natl Acad Sci US A 102, 17507-17512.

132. Tournier C, Aladenise S, Vialle S, et al. (2006) The effect of urinary $\mathrm{pH}$ on calcium oxalate relative supersaturation in healthy cats. Royal Canin, Research Center, Aimargues 
(France). http://www.royal-canin.de/fileadmin/downloads/ VMM_pH_and_CaOX_ESVCN_2006_poster.pdf (accessed 4 January 2011).

133. Smith BH, Stevenson AE \& Markwell PJ (1998) Urinary relative supersaturations of calcium oxalate and struvite in cats are influenced by diet. J Nutr 128, 2763S-2764S.

134. Robertson WG, Jones JS, Heaton MA, et al. (2002) Predicting the crystallization potential of urine from cats and dogs with respect to calcium oxalate and magnesium ammonium phosphate (struvite). J Nutr 132, 1637S-1641S.

135. Dru FS \& Roudebush P (2007) Evidence-based management of feline lower urinary tract disease. Vet Clin North Am Small Anim Pract 37, 533-558.

136. Dussol B, Iovanna C, Rotily M, et al. (2008) A randomized trial of low-animal-protein or high-fiber diets for secondary prevention of calcium nephrolithiasis. Nephron Clin Pract 110, c185-c194.

137. Trinchieri A, Mandressi A, Luongo P, et al. (1991) The influence of diet on urinary risk factors for stones in healthy subjects and idiopathic renal calcium stone formers. $\mathrm{Br} \mathrm{J}$ Urol 67, 230-236.

138. Johansson G, Backman U, Danielson BG, et al. (1980) Biochemical and clinical effects of the prophylactic treatment of renal calcium stones with magnesium hydroxide. J Urol 124, 770-774.

139. Rattan V, Sidhu H, Vaidyanathan S, et al. (1994) Effect of combined supplementation of magnesium oxide and pyridoxine in calcium-oxalate stone formers. Urol Res 22, 161-165.

140. Bonny O, Rubin A, Huang CL, et al. (2008) Mechanism of urinary calcium regulation by urinary magnesium and $\mathrm{pH}$. J Am Soc Nephrol 19, 1530-1537.

141. Schwartz BF, Bruce J, Leslie S, et al. (2001) Rethinking the role of urinary magnesium in calcium urolithiasis. J Endourol 15, 233-235.

142. Schwille PO, Schmiedl A, Herrmann U, et al. (1999) Magnesium, citrate, magnesium citrate and magnesium-alkali citrate as modulators of calcium oxalate crystallization in urine: observations in patients with recurrent idiopathic calcium urolithiasis. Urol Res 27, 117-126.

143. Ogawa Y, Yamaguchi K \& Morozumi M (1990) Effects of magnesium salts in preventing experimental oxalate urolithiasis in rats. J Urol 144, 385-389.

144. Ettinger B, Pak CY, Citron JT, et al. (1997) Potassiummagnesium citrate is an effective prophylaxis against recurrent calcium oxalate nephrolithiasis. J Urol 158, 2069-2073.

145. Tiselius HG (2001) Possibilities for preventing recurrent calcium stone formation: principles for the metabolic evaluation of patients with calcium stone disease. BJU Int 88, $158-168$.

146. Reed CF, Markwell PJ \& Jones CA (2000) The effect of oral magnesium salt administration on urinary calcium oxalate crystallization and agglomeration in cats. J Vet Intern Med 14, 383-383.

147. Pak CY (1991) Etiology and treatment of urolithiasis. Am J Kidney Dis 18, 624-637.

148. Allie-Hamdulay S \& Rodgers AL (2005) Prophylactic and therapeutic properties of a sodium citrate preparation in the management of calcium oxalate urolithiasis: randomized, placebo-controlled trial. Urol Res 33, 116-124.

149. Pak CY (1994) Citrate and renal calculi: an update. Miner Electrolyte Metab 20, 371-377.

150. Lulich JP, Osborne CA, Nagode LA, et al. (1991) Evaluation of urine and serum metabolites in miniature schnauzers with calcium oxalate urolithiasis. Am J Vet Res 52, 1583-1590.

151. Stevenson AE, Wrigglesworth DJ, Smith BH, et al. (2000) Effects of dietary potassium citrate supplementation on urine $\mathrm{pH}$ and urinary relative supersaturation of calcium oxalate and struvite in healthy dogs. Am J Vet Res 61, 430-435.

152. Cao LC, Boeve ER, de Bruijn WC, et al. (1997) Glycosaminoglycans and semisynthetic sulfated polysaccharides: an overview of their potential application in treatment of patients with urolithiasis. Urology 50, 173-183.

153. Buffington CA, Blaisdell JL, Binns SP Jr, et al. (1996) Decreased urine glycosaminoglycan excretion in cats with interstitial cystitis. J Urol 155, 1801-1804.

154. Strohmaier WL, Quack M, Wilbert DM, et al. (1989) Therapy of interstitial and radiogenic cystitis with D-glucosamine. Helv Chir Acta 56, 323-325.

155. Booth MP, Conners R, Rumsby G, et al. (2006) Structural basis of substrate specificity in human glyoxylate reductase/hydroxypyruvate reductase. J Mol Biol 360, 178-189.

156. Genolet R, Kersten S, Braissant O, et al. (2005) Promoter rearrangements cause species-specific hepatic regulation of the glyoxylate reductase/hydroxypyruvate reductase gene by the peroxisome proliferator-activated receptor $\alpha$. J Biol Chem 280, 24143-24152.

157. Xue HH, Sakaguchi T, Fujie M, et al. (1999) Flux of the L-serine metabolism in rabbit, human, and dog livers. Substantial contributions of both mitochondrial and peroxisomal serine:pyruvate/alanine:glyoxylate aminotransferase. J Biol Chem 274, 16028-16033. 